nized role of enteroviruses other than poliovirus in paralytic disease.

Respiratory infections are introduced with a challenging and controversial exposition of the principles of influenza vaccination by F.M. Davenport and A. V. Hennessy, a subject discussed further by E. C. Curnen. There follows an account by A. Isaacs of interferon, which offers an alternative method of approach to control of virus infections. R. M. Chanock and his associates give a useful review of newly discovered respiratory agents, sounding a proper note of caution in relation to interpretation of associations of these viruses with disease. Adenoviruses are surveyed briefly by W. P. Rowe, who also gives an excellent account of salivary gland virus and related infections of animals. Recent advances in varicella and measles are reviewed by S. L. Katz and his colleagues.

This book will be of particular interest to medical virologists, clinical pathologists and clinicians who are concerned with infectious diseases and children.

N. R. GRIST

\section{FACTS ABOUT INDUSTRIAL GROWTH}

Patterns of Industrial Growth, 1938-58

(Statistical Office of the United Nations, Department of Economics and Social Affairs.) Pp. viii +472 . (New York: United Nations; London: H.M. Stationery Office, 1960.) 8.50 dollars ; $60 \mathrm{~s}$. $6 d$.

THE statistical staff of the United Nations has made a heroic attempt to present a picture of industrial growth during twenty years in the 'free' world. In many of the tables the countries are grouped by continent or sub-continent; still more valuable is a four-fold classification by degree of industrialization. Data are given for 1938, 1948, 1953 and 1958 or for the periods lying between each. There are also separate data presented for each country.

The volume should be of the utmost use for students of economic growth, but it should also be serviceable to those of more general interests, whether political or technological. Many a generalization can now be checked by reference to the facts; it is likely that many misconceptions will be removed.

Some of the most prominent tables show growth expressed as average annual percentage rates of increase in each of the three periods. This gives the right orientation, since the most interesting problems of modern economics are concerned with the interrelations between growth-rates. The most central figure in the volume is that giving the average world figure for the annual rate of growth in mining and manufacturing together, namely 4.4 per cent per annum. The increase in output for each person employed in them was $2 \cdot 0$ per cent per annum or 2.7 per cent per annum-depending on the method of measurement.

The lowest class of countries, by degree of industrialization, showed an increase in production of 4.6 per cent per annum, and, it is satisfactory to note, an increase in output per person of 1.7 or 2.1 per cent. But the growth was from a very low level. The value added per person employed in manufacturing in the lowest class group in 1953 was less than a quarter of the value added for each person so employed in Europe, and little more than a twelfth of that per prrson employed in the United States and Canada (together).

There is a striking tabl correlation between the rate of increase of production and the rate of increase of production for each person. engaged. No support at all (pp. 26-9) can be found for the view that strong growth tends per se to be inflationary; there is no correlation between the rate of industrial growth and the degree of inflation as between countries.

Much selection was needed even for this massive volume. It could be argued that too much space is given to tables of percentage distribution between groups. The explanatory text is workmanlike and raises many interesting points, but in regard to causes we can still only be at the beginning of judgment.

ROY HARROD

\section{PLANT PATHOLOGY}

\section{Plant Disease Handbook}

By Dr. Cynthia Westcott. Second Edition. Pp. xii +825. (Princeton, N.J.: D. Van Nostrand Company, Inc, ; London : D. Van Nostrand Company, Ltd., 1960.) 101s. $6 d$.

7 HIS is an enlarged odition of the book by the same author written some ten years ago, and except for slight alterations the layout remains the same. This edition, however, deals with a much wider range of host plants, and there is a noticeable expansion in most sections as a result of discoveries in research during the past decade. The book in fact lists more than 2,000 diseases occurring on more than 1,000 host plants.

It is a large book of five chapters preceded by an author's note on "How to use this Book". The first three chapters are very short-Chapter 1 is the usual introduction to the subject describing the nature of plant diseasea and the principles underlying their prevention or control. Chapter 2 gives an up-to-date account of the chemicals used in control practices, and Chapter 3 is a list of the various plant pathogens, with special attention paid to the fungi, in the form of a short classification.

The next two chapters occupy nearly 700 pages between them and provide what we can call the substance of the book. Chapter 4 includes no less than 40 different types of disease placed in sections which have been created in somewhat arbitrary fashion according to symptoms shown by the hosts (for example, cankers, galls, leaf spots, mildews, rusts, wilts and so on). These sections are in alphabetical order, and in each, the various pathogens which can cause that type of disease appear in alphabetical order accompanied by details of suitable control measures, and the life-history and structure of the parasite. Chapter 5 is a list of host plants in alphabetical order according to the common name or the Latin name where the author considers this is more helpful in avoiding confusion. Below each host name is a full list of its diseases with short comments about the more important ones. At the end there are a glossary, a selected bibliography and a good index. For the purpose of emphasizing special diseases or important parasites there are about 100 illustrations in the form of photographs or line drawings. The paper and print are of the high quality which we always associate with American publications of this kind. 